\title{
An ENU-Induced Mutation of Cdh23 Causes Congenital Hearing Loss, but No Vestibular Dysfunction, in Mice
}

\author{
Shehnaaz S.M. Manji, ${ }^{*}$ Kerry A. Miller, ${ }^{*}$ \\ Louise H. Williams, ${ }^{*}$ Lotte Andreasen, ${ }^{*}$ \\ Maria Siboe, ${ }^{*}$ Elizabeth Rose, ${ }^{\dagger}$ Melanie Bahlo, ${ }^{\ddagger}$ \\ Michael Kuiper, ${ }^{\S}$ and Hans-Henrik M. Dah"* ${ }^{\star \uparrow}$ \\ From the Genetic Hearing Research Laboratory," Murdoch \\ Childrens Research Institute, Royal Children's Hospital, Parkville; \\ the Departments of Otolaryngology, ${ }^{\dagger}$ and Paediatrics, " University \\ of Melbourne, Parkville; the Bioinformatics Division, ${ }^{\ddagger}$ Walter $\&$ \\ Eliza Hall Institute, Parkville; and Victorian Partnership \\ Advanced Computing, ${ }^{\circledR}$ Carlton South, Victoria, Australia
}

Mutations in the human cadherin 23 ( $C D H 23)$ gene cause deafness, neurosensory, autosomal recessive 12 (DFNB12) nonsyndromic hearing loss or Usher syndrome, type 1D (characterized by hearing impairment, vestibular dysfunction, and visual impairment). Reported waltzer mouse strains each harbor a Cdb23-null mutation and present with hearing loss and vestibular dysfunction. Two additional Cdb23 mouse mutants, salsa and erlong, each carry a homozygous Cdb23 missense mutation and have progressive hearing loss. We report the identification of a novel mouse strain, jera, with inherited hearing loss caused by an $N$-ethyl- $N$-nitrosourea-induced c.7079T $>\mathrm{A}$ mutation in the $\mathrm{Cdb23}$ gene. The mutation generates a missense change, p.V2360E, in Cdh23. Affected mice have profound sensorineural deafness, with no vestibular dysfunction. The p.V2360E mutation is semidominant because heterozygous mice have milder and more progressive hearing loss in advanced age. The mutation affects a highly conserved $\mathrm{Ca}^{2+}$-binding motif in extracellular domain 22, thought to be important for $\mathrm{Cdb} 23$ structure and dimerization. Molecular modeling suggests that the $C d b 23^{\text {V2360E/V2360E }}$ mutation alters the structural conformation of the protein and affects $\mathrm{Ca}^{2+}$. binding properties. Similar to salsa mice, but in contrast to waltzer mice, hair bundle development is normal in jera and hearing loss appears to be due to the loss of tip links. Thus, jera is a novel mouse model for DFNB12. (Am J Pathol 2011, 179:903-914; DOI: 10.1016/j.ajpath.2011.04.002)
Deafness is the most common sensory impairment in humans, often incurring lifelong educational, social developmental, and economic costs. Hearing loss is a multifactorial disorder, caused by environmental or genetic factors or a combination of both. It is estimated that there are 100 mapped loci that may cause monogenic nonsyndromic hearing loss and $>400$ syndromes that include hearing as a feature. ${ }^{1}$ Nevertheless, when investigating a specific family affected by inherited hearing loss, the condition is usually transmitted as a monogenic disorder. It has become clear that different mutations in a gene can cause a variety of genetic and clinical features (eg, dominantly or recessively inherited hearing loss or syndromic or nonsyndromic hearing loss).

In humans, mutations in the cadherin $23(\mathrm{CDH} 23)$ gene cause autosomal recessively inherited nonsyndromic congenital deafness (DFNB12; Online Mendelian Inheritance of Man no. 601386; http://www.ncbi.n/m.nih.gov/ omim, last accessed March 29, 2011) or Usher syndrome, type 1D (USH1D; Online Mendelian Inheritance of Man no. 601067; http://www.ncbi.nlm.nih.gov/omim, last accessed March 29, 2011). USH1 is characterized by congenital hearing impairment, vestibular dysfunction, and visual impairment. DFNB12 deafness is usually caused by missense mutations in $\mathrm{CDH} 23$ alleles and USH1D by null mutations. ${ }^{2-7}$ A synonymous single-nucleotide polymorphism, Cdh23 ${ }^{753 \mathrm{~A}}$, is linked to age-related hearing loss in mice. ${ }^{8}$ Null mutations in mouse Cdh23 lead to the waltzer phenotype, characterized by hearing loss and vestibular dysfunction. ${ }^{9-13}$ Two $N$-ethyl-N-nitrosourea (ENU)-generated mouse strains, salsa and erlong, carry a recessive Cdh23 missense mutation. ${ }^{14,15}$ Both mutants have progressive hearing loss, with no vestibular abnormalities, and are, therefore, models for DFNB12 deafness. Retinal degeneration is not a clinical

Supported by grant 436944 from the National Health and Medical Research Council, the HEARing CRC, and J. \& J. Calvert-Jones.

Accepted for publication April 25, 2011.

Address reprint requests to Shehnaaz S.M. Manji, Ph.D., Genetic Hearing Research, Murdoch Childrens Research Institute, Royal Children's Hospital, Flemington Road, Parkville, Melbourne, VIC 3052, Australia. E-mail: shehnaaz.manji@mcri.edu.au. 
Table 1. Allelic Variants of $C d h 23$ in Mice

\begin{tabular}{|c|c|c|c|c|c|c|c|}
\hline Mouse model & Nucleotide change & $\begin{array}{l}\text { Amino acid } \\
\text { change }\end{array}$ & Exon & $\begin{array}{c}\text { EC } \\
\text { domain }\end{array}$ & Phenotype & Predicted effect & Reference \\
\hline jera & $7486 \mathrm{~T}>\mathrm{A}$ & V2360E & 52 & EC22 & DFNB12 & $\begin{array}{l}\text { Disruption of the } \\
\mathrm{Ca}^{+} \text {-binding motif }\end{array}$ & Present study \\
\hline erlong & $208 T>C$ & S70P & 3 & EC1 & DFNB12 & Loss of protein function & 15 \\
\hline salsa & $2210 A>T$ & E737V & 22 & EC7 & DFNB12 & $\begin{array}{l}\text { Disruption of the } \\
\mathrm{Ca} 2^{+} \text {-binding motif }\end{array}$ & 14 \\
\hline $\mathrm{Cdh} 23^{\mathrm{V}}$ & 834insG & N279EfsX39 & 9 & EC3 & USH1D & Premature stop codon & 13 \\
\hline Cdh23 VJ & 3505delG & E1169NfsX7 & 29 & EC11 & USH1D & Premature stop codon & 13 \\
\hline $\mathrm{Cdh} 23^{\mathrm{V}-2 \mathrm{~J}}$ & $4104+1 G>A$ & & 31 & EC13 & USH1D & Splice-site mutation & 9 \\
\hline Cdh23 $2-3 \mathrm{~J}$ & $5291 \mathrm{G}>\mathrm{A}$ & W1764X & 40 & EC17 & USH1D & $\begin{array}{l}\text { Loss of functional } \\
\text { domains }\end{array}$ & 10 \\
\hline$C d h 23^{\vee-4 J}$ & 8152del9 & N2718del3 & 56 & EC25 & USH1D & $\begin{array}{l}\text { Disruption of the } \\
\mathrm{Ca} 2^{+} \text {-binding motif }\end{array}$ & 10 \\
\hline$C d h 23^{\vee-5 J}$ & $8803 C>T$ & $\mathrm{R} 2935 \mathrm{X}$ & 60 & EC27 & USH1D & $\begin{array}{l}\text { Loss of functional } \\
\text { domains }\end{array}$ & 10 \\
\hline$C d h 23^{\vee-6 J}$ & $904 \mathrm{G}>\mathrm{T}$ & E302X & 9 & EC3 & USH1D & $\begin{array}{l}\text { Loss of functional } \\
\text { domains }\end{array}$ & 9 \\
\hline$C d h 23^{V-7 J}$ & 3589delT & Y1197MfsX47 & 30 & EC11 & USH1D & Premature stop codon & 9 \\
\hline Cdh23 $3^{\text {-ngt }}$ & 145 delG & G49VfsX3 & 2 & EC1 & USH1D & Premature stop codon & 12 \\
\hline Cdh23 V-Alb & $1635 \mathrm{C}>$ Tdel119 & G545G & 15 & EC5 & USH1D & $\begin{array}{l}\text { Generates ectopic } \\
\text { splice site }\end{array}$ & 9 \\
\hline Cdh23Vbus & $9633+1 G>A$ & & 67 & CYTO & USH1D & Splice-site mutation & 11 \\
\hline Cdh23 $3^{\text {Ahl }}$ & $753 G>A$ & P251P & 7 & EC3 & $\mathrm{AHL}$ & $\begin{array}{l}\text { In-frame skipping of } \\
\text { exon } 7\end{array}$ & 8 \\
\hline
\end{tabular}

feature in any of the mice with Cdh23 mutations. Previously reported allelic variants of $\mathrm{Cdh} 23$ in mice are detailed in Table 1.

Auditory hair cells, located within the organ of Corti, have a bundle of stereocilia with a central kinocilium, located at their apical surface. These structures act as mechanoelectrical transduction sensors and are, therefore, essential for normal hearing. Stereocilia and kinocilium are connected via transient lateral links, kinociliary links, and tip links in immature cochlear hair cells (Figure 1). Cdh23, together with protocadherin 15 (Pcdh15), is a major component of these links. ${ }^{16-18}$ The tip links are connected to transduction channels on the stereocilia, in which the movement of stereocilia causes the rigid tip links to pull open the transduction channels and thereby initiate mechanotransduction. ${ }^{19,20}$ Therefore, Cdh23 is thought to be directly involved in this process. Also,

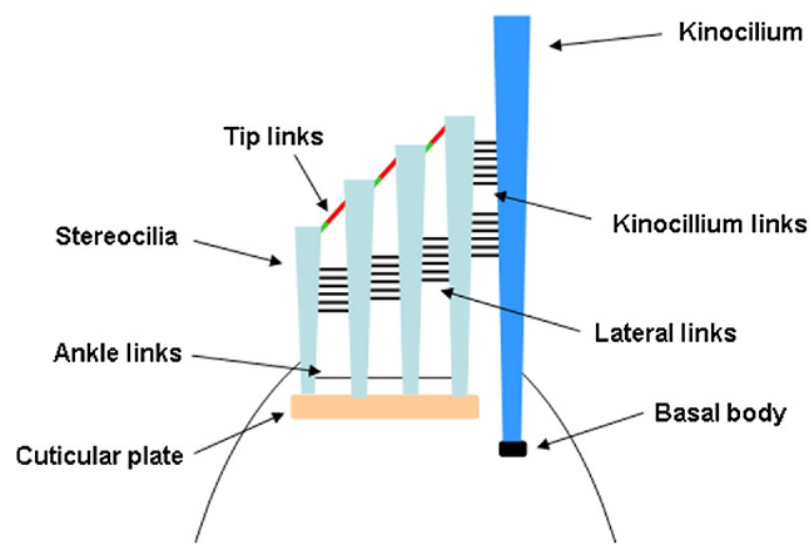

Figure 1. Schematic diagram of stereocilia and kinocilium location in an immature $(<\mathrm{P} 8)$ cochlear hair cell and the position of associated tip links formed by the interaction of Cdh23 (red) and Pcdh15 (green).
Cdh23 may be involved in hair bundle development, as this process is defective in waltzer mice with Cdh23-null mutations. ${ }^{9,12,13,21-27}$ salsa mice confirmed the role of Cdh23 in mechanotransduction, as hair cells and hair bundles develop normally, but the function of these cells was affected. ${ }^{14} \mathrm{~A}$ recent report by Lelli et $\mathrm{al}^{28}$ provided physiological evidence to support the involvement of $\mathrm{CDH} 23$ and $\mathrm{PCDH} 15 \mathrm{~N}$-terminal regions in tip link formation. The Cdh23 gene codes for several different splice isoforms. ${ }^{10}$ The longest isoform of Cdh23 in mouse comprises 71 exons and codes for a 3354-amino acid protein. It is expressed in the mouse inner ear but not in the mouse retina. ${ }^{29}$ Cadherins are adhesion molecules that mediate $\mathrm{Ca}^{2+}$-dependent cell-cell adhesion via extracellular (EC) domains. Cdh23 contains 27 EC domains; and each EC domain consists of three $\mathrm{Ca}^{2+}$-binding motifs (consensus sequences DXD, LDRE, and DXNDN) that are essential for dimerization, linearization, and rigidification. ${ }^{10}$ Different EC domains are affected in waltzer, salsa, and erlong mice. We have screened ENU mouse mutant libraries for recessively inherited hearing loss; in this study, we describe a novel mouse strain, jera, with a missense mutation in Cdh23. The hearing loss in jera is more severe than that in salsa and erlong. Similar to salsa and erlong, the development of hair bundles appears normal in jera; therefore, it is a new model for DFNB12.

\section{Materials and Methods}

\section{jera Mouse}

This project was approved by the Royal Children's Hospital Animal Ethics Committee (application numbers A488 and 585). The jera mouse was generated by ENU mutagenesis at the Australian Phenomics Facility, Can- 
berra, in a program aimed at identifying recessive conditions. Male C57BL/6 mice were treated weekly for 3 weeks with $100 \mathrm{mg} / \mathrm{kg}$ ENU. To identify recessive phenotypes, $G_{2}$ siblings were mated to generate $G_{3}$ offspring homozygous for ENU mutations. We screened 5750 ENU $\mathrm{C} 57 \mathrm{BL} / 6$ mutant $\mathrm{G}_{3}$ mice for hearing loss. The initial click box hearing test elicits a Preyer reflex or a startle response in hearing mice by producing an $18.9-\mathrm{kHz}$ burst of 106-dB sound pressure level (SPL) at a distance of 10 $\mathrm{cm}$ (Institute of Hearing Research, Nottingham, UK). Mice that failed the initial click box hearing test were subsequently tested by an evoked auditory brainstem response (ABR) (Bio-logic Systems Corp, Chicago, IL). Subdermal active, reference, and ground electrodes were placed at the vertex, ventrolateral to the left ear, and the abdomen, respectively, of the anesthetized mouse. A specific auditory stimulus in the form of broadband clicks was delivered in a range of decibel SPLs and the ABR was recorded. Mice were also screened for the presence of vestibular dysfunction that was identified by the display of hyperactivity that manifests as circling, head tossing/ tilting, and/or star-gazing behavior.

\section{Heritability and Genetic Mapping}

Mice that failed both the click box and ABR hearing test were intercrossed to the congenic strain C57BL/10 for heritability testing. We expected $25 \%$ of the $\mathrm{G}_{2}$ offspring to be deaf if the mutation was recessively inherited and fully penetrant. Deaf mice were then outcrossed to the $\mathrm{CBA} / \mathrm{H}$ strain, and the $\mathrm{F}_{2}$ progeny were generated for homozygosity mapping and subsequent identification of candidate regions. Genomic DNA samples from 10 affected mice were analyzed by genomewide scans using 120 microsatellite markers (AGRF, Melbourne, Australia). Fine mapping was performed using Amplifluor-based single-nucleotide polymorphism assays (Australian Phenomics Facility) on 53 additional affected mice. For our statistical analysis, we used the normal approximation to the binomial test for proportions of homozygous C57BL/6 genotypes (hearing loss mutants) to map the deafness loci. In chromosome regions of linkage, the proportion of homozygous C57BL/6 genotypes would approach 1.0; at unlinked loci, this proportion would be 0.25 . Linkage intervals were examined for candidate genes using the UCSC genome bioinformatics (http://genome.ucsc.edu).

\section{Mutation Analysis}

To scan for mutations in the Cdh23 gene (transcript reference, ENSMUST00000105464; protein reference, ENSMUSP00000101104), $1 \mu \mathrm{g}$ of total RNA from mouse brain was reverse transcribed using random hexamers (Roche, Penzberg, Germany). cDNA products were PCR amplified using HotStar Taq polymerase (Qiagen, Hilden, Germany) with 16 primer sets, generating overlapping amplicons that covered the 10,572-bp Cdh23 RNA coding region transcript and most of the $5^{\prime}$ and $3^{\prime}$ untranslated regions. The PCR products were sequenced in both directions using a Big Dye Sequencing kit, version 3.1 ( $\mathrm{ABI}$, Carlsbad, $\mathrm{CA}$ ) and analyzed on an Applied Biosystems DNA Analyzer (model $3730 \mathrm{xl} ; \mathrm{ABI}$ ). DNA sequences from deaf and hearing littermates were compared using Mutation Surveyor version 2.60 (SoftGenetics, State College, PA).

\section{Tissue Collection}

Mice [postnatal day (P) 14 and older] were anesthetized with isoflurane and euthanized by cervical dislocation, whereas mice younger than P14 were euthanized by tribromoethanol (Avertin) overdose, according to the $\mathrm{Na}$ tional Health and Medical Research Council Australian code of practice for the care and use of animals for scientific purposes (Royal Children's Hospital Animal Ethics Committee approval A488 and 585). Intact cochleae were surgically removed using a posterolateral approach, and the brain was dissected from mice of the same strain, age, and sex. Brains were stored in RNAlater buffer (Qiagen $\mathrm{GmbH}$, Hilden, Germany) at $-70^{\circ} \mathrm{C}$ for total RNA isolation. Adult mouse cochleae were prepared as described by Whitlon et $\mathrm{al}^{30}$ and processed for H\&E staining. P5 mouse half heads were fixed in $4 \%$ paraformaldehyde at $4^{\circ} \mathrm{C}$ for 2 hours, followed by PBS washes three times for 20 minutes, before isolation of the cochlear sensory epithelium (SE) for whole-mount immunofluorescence analysis. The P14 to P30 half heads were fixed in $4 \%$ paraformaldehyde at room temperature for 2 hours before PBS washes and fine dissection.

\section{H\&E Staining}

Processed cochleae were embedded in OCT (Sakura Finetek USA, Inc., Torrance, CA) and sectioned (10 $\mu \mathrm{m})$ using a cryostat (Leica Microsystems, Wetzler, Germany) onto SuperfrostPlus microscope slides (Gerhard Menzel $\mathrm{GmbH}$, Braunschweig, Germany) and stored at $-20^{\circ} \mathrm{C}$ until use. For H\&E staining, cochlear sections were processed through H\&E staining, coverslipped with Pertex mounting media, and visualized using a Leica DMI3000 microscope (Leica Microsystems).

\section{Immunohistochemical Staining for Cdh23 Protein}

Cochlear SE isolated from P5 to P30 mice were processed for immunohistochemical staining using either a cadherin 23 antibody (provided by Prof. Thomas Friedman and Dr. Ayala Lagziel, National Institute on Deafness and Other Communication Disorders, Bethesda, MD ${ }^{29}$ or a polyclonal rabbit anti-human Cdh23 antibody (Santa Cruz Biotechnology, Inc., Santa Cruz, CA). Briefly, SEs were rinsed three times in PBS and then permeabilized for 30 minutes with $0.3 \%$ to $1 \%$ Triton X-100 (SigmaAldrich, St. Louis, MO) in PBS. SEs were then blocked in $5 \%$ to $10 \%$ goat serum (with or without $2 \%$ bovine serum albumin) in PBS for 1 to 2 hours. Isolated SEs were incubated with an anti-Cdh23 antibody [1:250 (antibody from National Institute on Deafness and Other Communication Disorders) or 1:500 (antibody from Santa Cruz Biotechnology, Inc.), respectively] overnight at $4^{\circ} \mathrm{C}$. SEs 
were rinsed three times in PBS with 10- to 20-minute intervals. This was followed by incubation with an Alexa Fluor 488- or an Alexa Fluor 594-conjugated goat antirabbit IgG antibody (Invitrogen-Molecular Probes, Eugene, OR) in $1 \%$ to $10 \%$ goat serum in PBS (1:2500) at room temperature for 2 hours and washes three times with PBS. SEs were counterstained with Alexa Fluor 594 or Alexa Fluor 488-phalloidin (1:250; Molecular Probes) in PBS for 20 minutes, then washed a further three times with PBS for 10 minutes. SEs were incubated with a rabbit IgG antibody (Invitrogen Corp., Carlsbad, CA) as a control. SEs were positioned on slides, mounted with Prolong Gold Antifade reagent with DAPI (Molecular Probes), and viewed using a Carl Zeiss Imager.M1 (MTB2004 AXIO; Carl Zeiss Microlmaging GmbH, Gottingen, Germany) or a Leica TCS SP2 laser scanning confocal microscope. Images were generated using AxioVision Rel. 4.7 or Leica Confocal Software (Leica Microsystems).

\section{Scanning Electron Microscopy}

Inner ears from P14, P30, and 13-week-old mice were isolated; the round and oval windows were cleared; and the cochlear apex was pierced to allow thorough perfusion of the fixative. Inner ears were fixed in $2.5 \%$ glutaraldehyde in $0.1 \mathrm{~mol} / \mathrm{L}$ sodium cacodylate buffer $(\mathrm{pH} 7.4)$ with $3 \mathrm{mmol} / \mathrm{L} \mathrm{CaCl} \mathrm{C}_{2}$ for 3 hours at room temperature. Samples were then washed in PBS and further dissected by removing the bony shell, stria vascularis, and Reissner's and tectorial membranes to reveal the cochlear SE. Cochlear specimens were incubated in osmium tetroxide for 2.5 hours, washed, dehydrated through an ethanol gradient, and then critical point dried (CPD030; BalTec GmbH, Schalksmuhle, Germany). Specimens were mounted on stubs using a conductive silver paint, gold sputter coated (Edwards S150B sputter coater, approximately $10 \mathrm{~nm}$; Edwards High Vacuum Inc., Crawley, West Sussex, UK), and viewed using a Philips XL30 FE scanning electron microscope (Philips Electron Optics, Eindhoven, the Netherlands).

\section{Molecular Modeling of Cdh23 Mutations}

The mouse E-cadherin 1EDH crystal structure ${ }^{31}$ was used to model the effect of the Cdh23 p.V2360E mutation on the structure and function of the protein. Both wild-type and mutant models were simulated for 4 nanoseconds of fully solvated molecular dynamics at $310 \mathrm{~K}\left(36.85^{\circ} \mathrm{C}\right)$ using the NAMD software package (http://mww.ks.uiuc.edu/Research/namd) ${ }^{32}$ Simulations were run with the calcium ions in the crystallographically identified binding sites and with the calcium ions moved away from the binding sites. Molecular modeling images were generated using the VMD software package (http://www.ks.uiuc.edu/Research/vmd). ${ }^{33}$

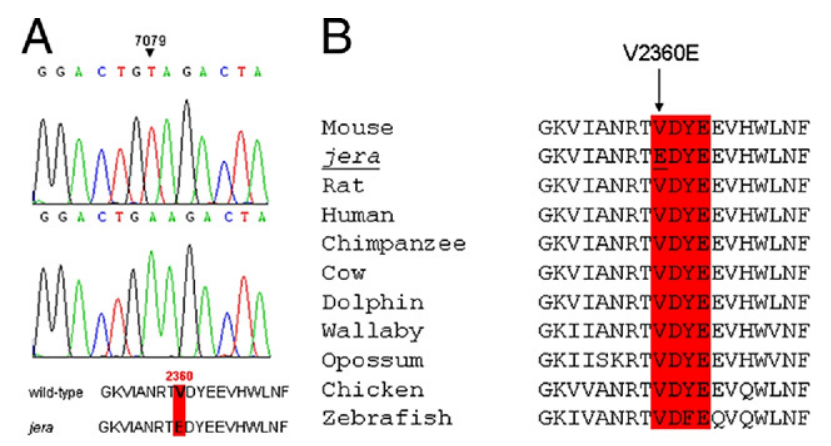

Figure 2. A: Chromatograms of wild-type (top) and jera (bottom) mice. A $\mathrm{T}>\mathrm{A}$ transversion of nucleotide 7079 , localized in the EC22 domain, is shown in the $C d h 23^{\mathrm{V} 2360 \mathrm{E} / \mathrm{V} 2360 \mathrm{E}}$ mutant, resulting in amino acid 2360 changing from a valine (V) to a glutamic acid (E). B: The mutation is localized in a highly conserved LDRE $\mathrm{Ca}^{2+}$-binding domain (red).

\section{Results}

\section{jera Mice Harbor a Cdh23 Point Mutation}

Genomewide homozygosity mapping, followed by fine mapping, positioned the deafness locus in the jera mutant to mouse chromosome 10 , between nucleotides $58,149,600$ and $66,453,600$. Because this region contained the known "deafness" gene, Cdh23, we sequenced the Cdh23 cDNA. A novel mutation was detected: a T-to-A transversion at nucleotide position 7079 (c.7079T >A) in exon 52, resulting in amino acid 2360 changing from valine to glutamic acid ( $p . V 2360 E)$ (Figure 2A). This amino acid is within a highly conserved $\mathrm{Ca}^{2+}$ binding motif (Figure 2B) in EC domain 22. All reported Cdh23 mutations in mouse, including waltzer (except one Cdh23 ${ }^{\text {bus }}$ ), salsa, erlong, and jera, are located in the EC domains (Figure 3A). Many missense mutations that cause DFNB12, including those in salsa and jera, affect the $\mathrm{Ca}^{2+}$-binding domains (ie, DXD, LDRE, and DXNDN). Nonsense and splice-site mutations that lead to $\mathrm{CDH} 23$ null alleles cause USHD1 and the waltzer phenotype in mice (Figure 3B).

\section{Protein Conformation Is Disrupted in Cdh23 ${ }^{\text {V2360EN2360E }}$ Mice}

To assess the structural consequences of the Cdh23 p.V2360E mutation, we examined computer-generated molecular models of the EC Cdh23 calcium-binding domains based on the mouse E-cadherin 1EDH crystal structure. ${ }^{31}$ The amino acid that corresponds to Cdh23 Val2360 in the mouse E-cadherin 1EDH fragment is Leu66. In the mutant modeling simulations, Leu66 is, therefore, replaced with Glu66. The modeling studies revealed that EC domains of E-cadherins form parallel symmetric dimers, held together primarily by a network of hydrogen bonding at an interface region coordinated by calcium ions (Figure 4A). Removal of the calcium ions allows greater flexibility in the calcium-binding regions and, consequently, appears to destabilize the dimer complex. ${ }^{35}$ The Leu66 residue stabilizes the EC domains by participating in hydrophobic interactions, with adjacent residues directing the side chain portion internally. 
A

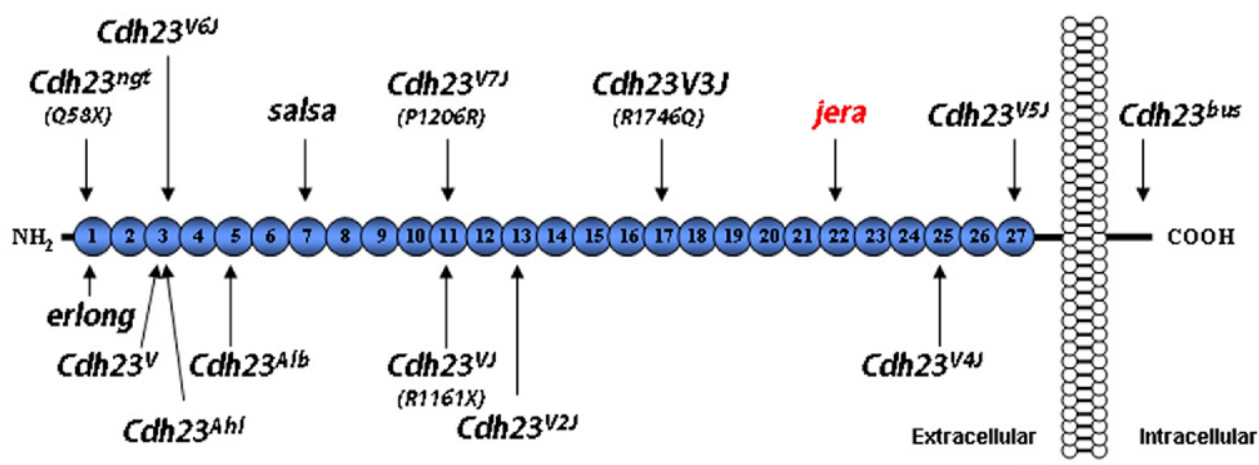

Cell membrane

$\mathrm{B}$

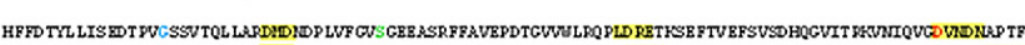

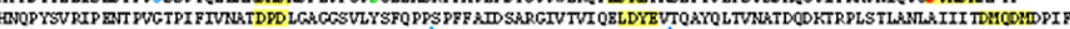

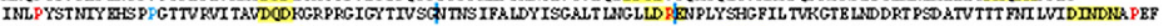

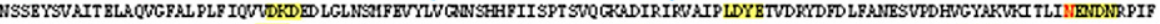

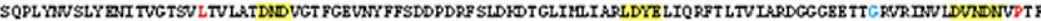

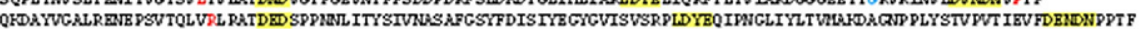

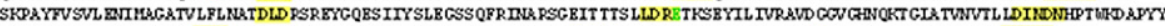

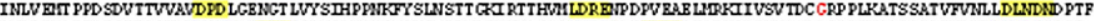

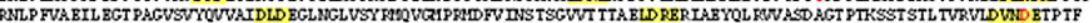

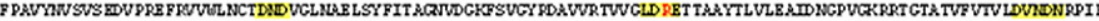

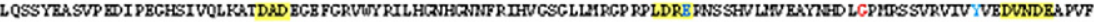

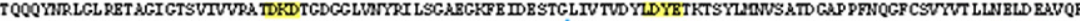

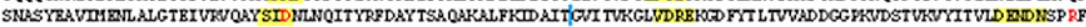

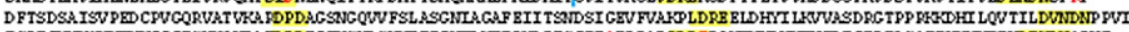

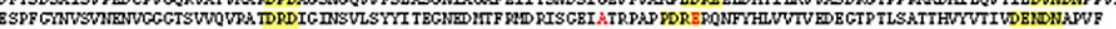

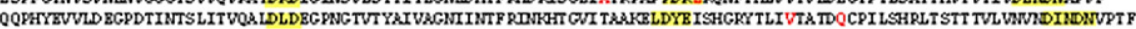

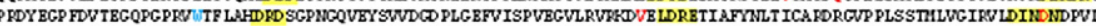

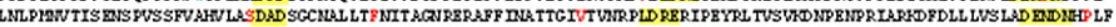

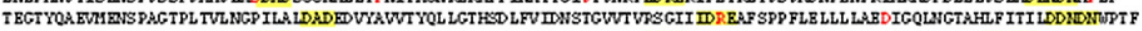

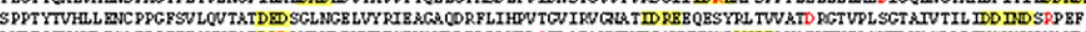

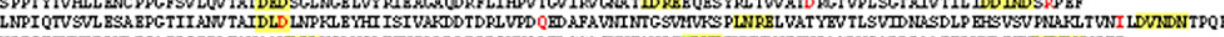

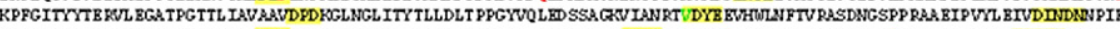

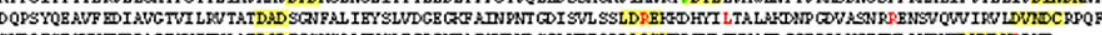
SKPOFST SVYZNE PACTSVITHLATDOD ECSNSOLTYSLE GPGIEA FSVDAD SGLVTT ORP LOSYERRNL TWVATD GGE PPLUCT TIL LVEVIDVDDNPPVF

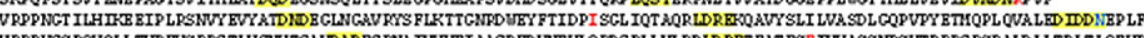

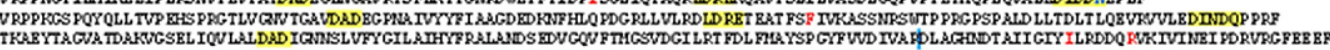

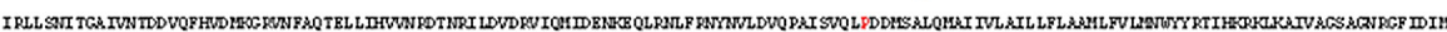

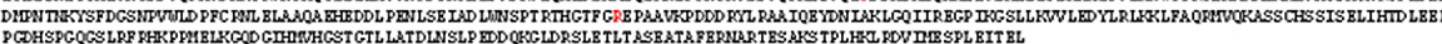

Figure 3. A: Schematic diagram of Cdh23 protein structure showing the location of the jera mutation (red) relative to waltzer, salsa, and erlong mutations. USH1D human mutations within close proximity to a reported waltzer mutation are shown in parentheses. ${ }^{5,34}$ Details of these mouse mutations are included in Table 1. B: The $27 \mathrm{EC}$ domain sequences of mouse Cdh23. Yellow boxes depict the calcium-binding motifs DXD, LDRE, and DXNDN within each EC domain. The positions of reported waltzer (blue); salsa, erlong, and jera (green); and known human DFNB12 (red) mutations are shown.

Simulations in which Leu66 was replaced with Glu66 consistently showed that Glu66 is repelled from the hydrophobic pocket and is instead directing itself externally to the solvent, causing a local conformational change. The simulations also suggest that the mutated residue forms a new
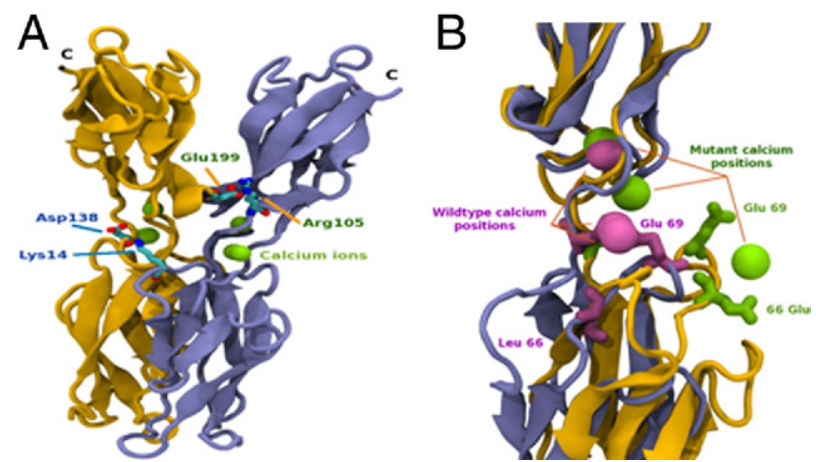

Figure 4. A: Schematic diagram of the wild-type dimeric E-cadherin $2.0 \mathrm{~A}$ crystal structure (1EDH) highlighting the amino acids that are involved in stabilizing the $\mathrm{Ca}^{2+}$ ions in the E-cadherin domains. B: Protein remodeling of a Cdh23 p.V2360E mutation showing the $\mathrm{Ca}^{2+}$ ions and amino acids for the wild-type (pink) and mutant (green) molecules. The mutation alters the structural conformation, interfering with the $\mathrm{Ca}^{2+}$ interaction that results in destabilization of the region. calcium-binding arrangement with residue Asp67, thereby severely affecting calcium-binding properties. Finally, the mutant form appears to lead to other structural changes in adjacent $\beta$ sheets, altering the positioning of Lys 14 , which is likely to affect its ability to form intermolecular salt bridging with Glu138. These studies suggest that the Cdh23

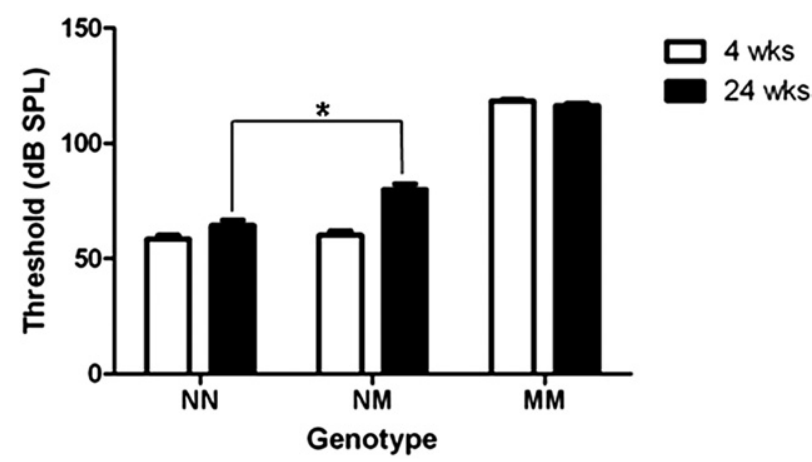

Figure 5. Hearing profile of the $C d h 23^{\mathrm{V} 2360 \mathrm{E} / \mathrm{V} 2360 \mathrm{E}}$ mutant, compared with littermates. The $C d h 23^{\mathrm{V} 2360 \mathrm{E} / \mathrm{V} 2360 \mathrm{E}}$ homozygous mutant (MM) displays profound hearing loss at the age of 4 weeks. A two-way analysis of variance revealed that the $C d h 23^{\mathrm{V} 2360 \mathrm{E} /+}$ heterozygotes (NM) exhibit an elevated hearing threshold at the age of 24 weeks compared with $C d h 23^{+/+}$wild-type (NN) littermates $\left({ }^{*} P=0.0018\right)$. 


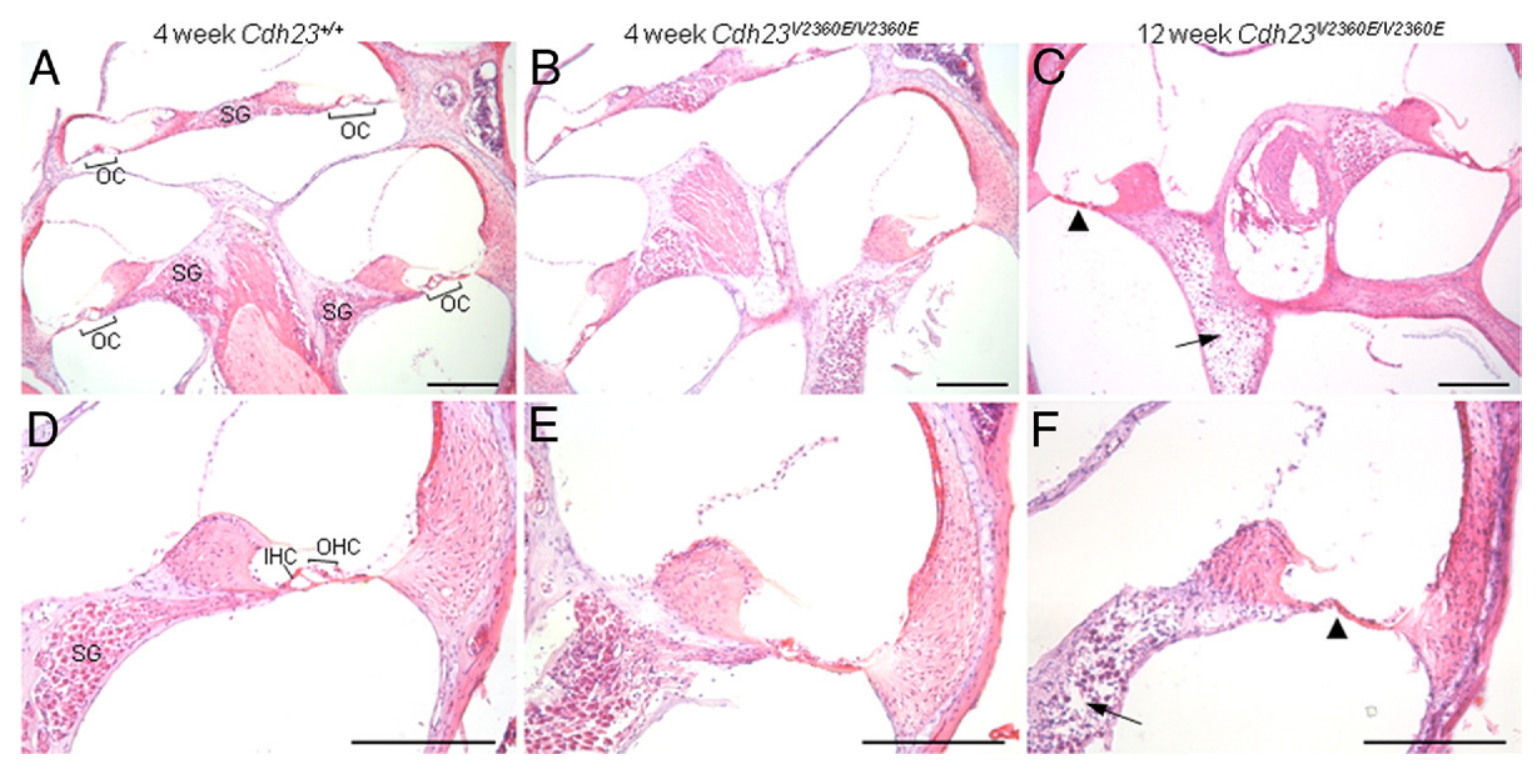

Figure 6. H\&E staining of $C d h 23^{\mathrm{V} 2360 \mathrm{E} / \mathrm{V} 2360 \mathrm{E}}$ and $C d h 23^{+/+}$cochleae. A and D: Normal cochlear morphological features $\left(C d h 23^{+/+}\right.$at 4 weeks). B and E: Mutant cochleae at 4 weeks showed modest signs of degeneration with a slight collapse of the OC in the basal region. $\mathbf{C}$ and $\mathbf{F}$ : At the age of 12 weeks, cochleae from Cdh $23^{\mathrm{V} 2360 \mathrm{E} / \mathrm{V} 2360 \mathrm{E}}$ mice show degeneration of the basal through the midcochlear turns, as seen by collapse of the OC (arrowhead) and loss of SG neurons (arrow). D, E, and F: The basal cochlear turn. OC indicates organ of Corti; SG, spiral ganglion. Scale bar $=200 \mu \mathrm{m}$.

p.V2360E mutation alters the structural conformation of the protein and affects $\mathrm{Ca}^{2+}$ binding (Figure 4B).

\section{Loss of Auditory Function in Cdh23 $2360 E$ N2360E Mice}

The effect of the Cdh23 p.V2360E mutation on auditory function was assessed by ABR (Figure 5). The homozygous mutant, Cdh23 ${ }^{\mathrm{V} 2360 \mathrm{E} N 2360 \mathrm{E}}$, displays profound hearing loss at 4 weeks (>120 dB SPL), whereas ABR thresholds were within the normal range in 4-week-old Cdh2 $23^{\mathrm{V} 2360 \mathrm{E} /+}$ and $\mathrm{Cdh} 23^{+/+}$mice. Cdh $23^{+/+}$mice show a moderate increase in hearing thresholds with increasing age, which we attribute to the presence of the agerelated hearing loss Cdh23 ${ }^{753 \mathrm{~A}}$ allele in C57BL6/J mice. ${ }^{8}$ However, Cdh23 ${ }^{\mathrm{V} 2360 \mathrm{E} /+}$ heterozygous mice exhibit a statistically significant $(P=0.0018)$ increase in hearing thresholds at the age of 24 weeks when compared with Cdh $23^{+/+}$wild-type littermates using two-way analysis of variance (Figure 5). There was no sign of vestibular dysfunction in jera because behavioral test results, including movement, circling, head tossing/tilting, star-gazing behavior, and righting response (curl trunk test), were normal in all three genotypes.

\section{Abnormal Cochlear Morphological Features in Cdh23 ${ }^{\text {V2360E }}$ 2360E Mice}

A comparison of H\&E-stained cochlear sections from 4-week-old Cdh23 $\mathrm{V} 2360 \mathrm{E} N 2360 \mathrm{E}, \mathrm{Cdh} 23^{\mathrm{V} 2360 \mathrm{E} /+}$, and Cdh $23^{+/+}$mice revealed only minor differences in the mutant mice. There was some indication of hair cell degeneration in the basal cochlear region occurring in the mutant mouse because the tunnel of Corti was less well formed than in $\mathrm{Cdh}_{2} 3^{+/+}$mice at this age (Figure 6, A, B,
$D$, and E). However, at the ages of 8 weeks (data not shown) and 12 weeks, signs of hair cell degeneration, leading to collapse of the organ of Corti and loss of spiral ganglion neurons, were clearly apparent in the basal and midcochlear turns (Figure 6, C and F) of Cdh23 ${ }^{\mathrm{V} 2360 \mathrm{EN} 2360 \mathrm{E}}$ mice. Cochlear morphological features in Cdh23 $2360 \mathrm{E} /+$ mice resembled those of wild-type mice.

\section{Cdh23 Expression Is Lost in}

\section{Cdh23 ${ }^{\text {V2360EN2360E }}$ Mice}

Immunofluorescence analysis was performed using an antiCdh23 antibody on cochlear SE from Cdh23V2360EN2360E, Cdh23 $22360 \mathrm{E} /+$, and Cdh23 $3^{+/+}$mice. Confocal microscopy confirmed that expression of Cdh23 protein was localized at the stereocilia of both the outer hair cells (OHCs) and inner hair cells (IHCs) of hearing mice up to $\mathrm{P} 14$, when similar levels were observed in the SE from Cdh23 $3^{\mathrm{V} 2360 \mathrm{E} N 2360 \mathrm{E}}$ and $\mathrm{Cdh} 23^{+/+}$mice. A comparison of

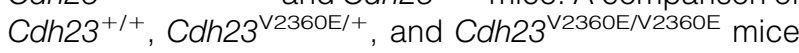
at P30 shows that $\mathrm{Cdh} 23$ expression is lost in both $\mathrm{OHCs}$ and IHCs of Cdh23 ${ }^{\mathrm{V} 2360 \mathrm{E} N 2360 \mathrm{E}}$ mice by this age (Figure 7). There also appeared to be reduced levels of Cdh23 mRNA expression in the hair cells of both P2

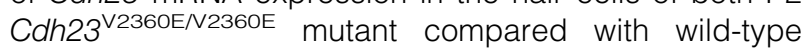
Cdh $23^{+/+}$mice (Figure 8).

\section{Cdh23 ${ }^{\text {V2360ENV2360E }}$ Mice Exhibit Hair Cell Degeneration and Loss of Stereocilia Tenting}

An examination of cochlear SEs using scanning electron microscopy (SEM) revealed that, although hair cells appear normal at P14 (data not shown), by P30, there was significant loss of hair cells (primarily $\mathrm{OHCs}$ ) in the basal through the midcochlear regions (Figure 9, A and B). P30 

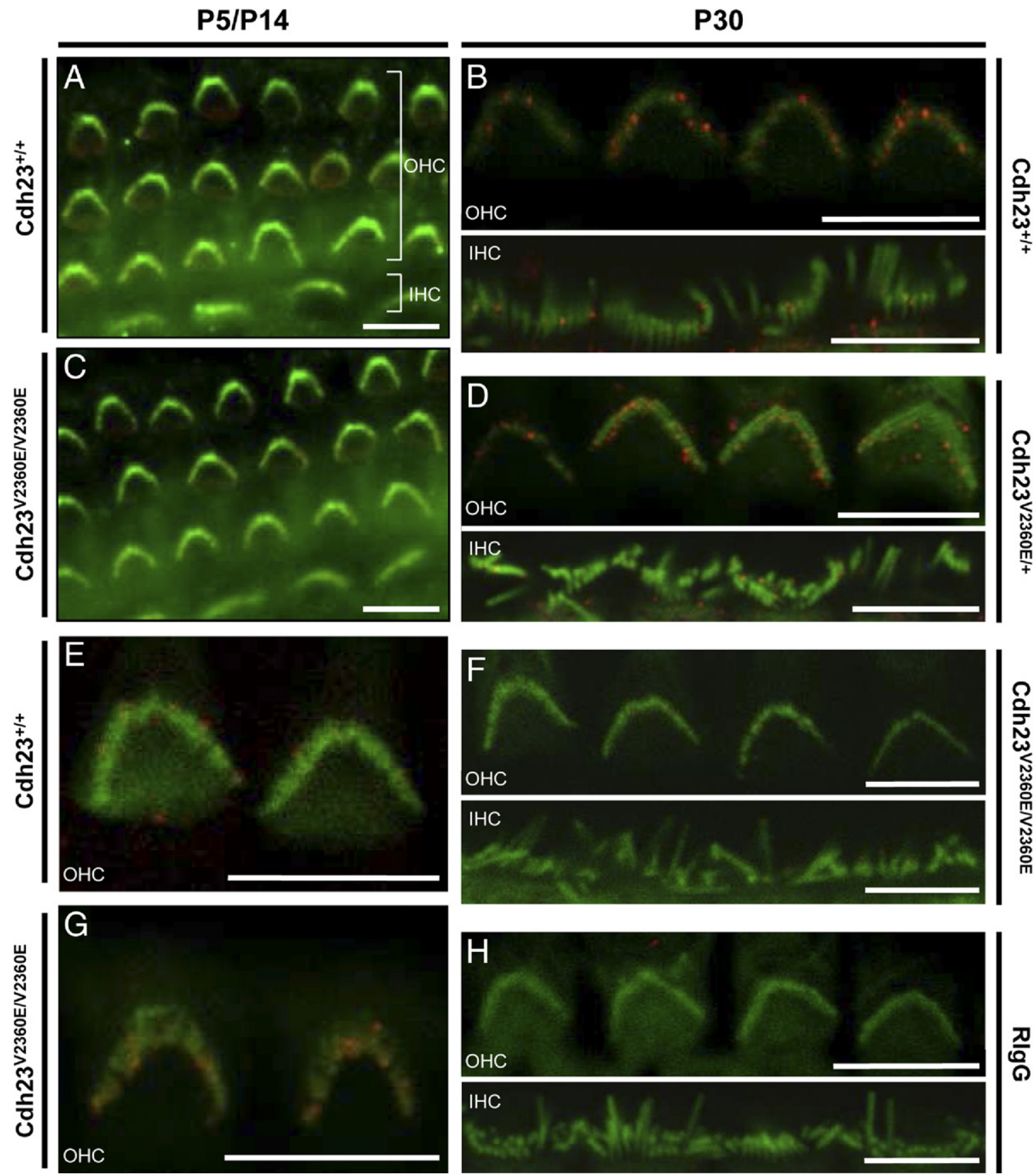

Figure 7. Immunofluorescence of whole mount cochlear SE. Stereocilia, labeled with phalloidin (red in $\mathbf{A}$ and $\mathbf{C}$ and green in $\mathbf{B}$ and $\mathbf{D}-\mathbf{H}$ ), are arranged normally in wild-type, heterozygote, and mutant mice. Levels of Cdh23 protein (green in $\mathbf{A}$ and $\mathbf{C}$ and red in $\mathbf{B}$ and $\mathbf{D}-\mathbf{H}$ ) localizing to the stereocilia appear normal at P5

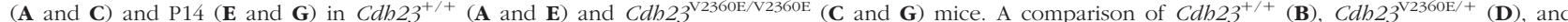
Cdh $23^{\mathrm{V} 2360 \mathrm{E} / \mathrm{V} 2360 \mathrm{E}}$ (F) mice at P30 shows Cdh23 expression is lost in both the OHCs and IHCs of Cdh2 $3^{\mathrm{V} 2360 \mathrm{E} / \mathrm{V} 2360 \mathrm{E}}$ mice by this age. Isotype control showing no nonspecific staining $(\mathbf{H})$. Scale bar $=8 \mu \mathrm{m}$. RIgG indicates rabbit.

Cdh23 ${ }^{\mathrm{V} 2360 \mathrm{E} / \mathrm{V} 2360 \mathrm{E}}$-mutant cochleae also showed a lack of stereociliary tip tenting of $\mathrm{IHC}$ second tallest row ste-

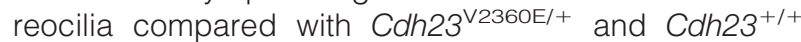
mice, indicative of disrupted tip links (Figure 9, G-I). As seen in the IHCs of $\mathrm{Cdh}_{2} 3^{+/+}$mice (Figure 9, J-L), this row of stereocilia commonly has pointed tips (examples are indicated by the arrowheads in Figure 9K), attributable to membrane tenting that is thought to occur because of the pulling force of the tip link that connects the top of these stereocilia to midway up the tallest row of stereocilia. $\mathrm{OHC}$ hair bundles appeared normal in Cdh23 ${ }^{\mathrm{V} 2360 \mathrm{E} / \mathrm{V} 2360 \mathrm{E}}$ mice, with lateral links seen between stereocilia (Figure 9, M-O).

\section{Hair Cell Degeneration Is Apparent in Aging Cdh23 ${ }^{\text {V2360E } /+}$ Mice}

Because of the increased hearing thresholds observed in Cdh23 ${ }^{\mathrm{V} 2360 \mathrm{E} /+}$ mice at 24 weeks, we used SEM to exam- 


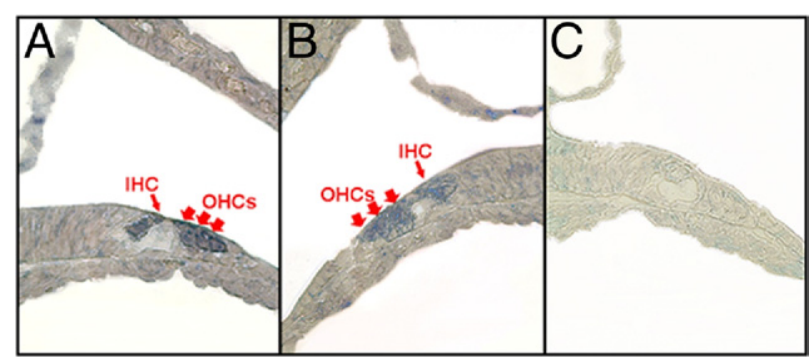

Figure 8. In situ hybridization of Cdh23 in developing mouse cochlea. Cdh23 expression was observed in both the IHCs and OHCs of $C d h 23^{+/+}$

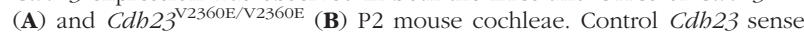
probe $(\mathbf{C})$.

ine cochleae from 13-week-old Cdh23 ${ }^{\mathrm{V} 2360 \mathrm{E} /+}$ and Cdh $23^{+/+}$mice to determine whether there were any observable differences between hair cells from these

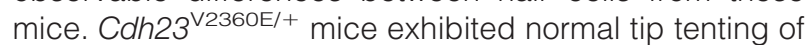
IHC stereocilia (Figure 10, G-I); however, there was evidence of hair cell degeneration in the basal cochlear turn, with approximately $50 \%$ of $\mathrm{OHCs}$ missing in this region (Figure 10, A-C).

\section{Discussion}

In this study, we identified and characterized a novel ENU-generated mouse model, jera, with inherited hearing loss because of a c.7079T $>$ A mutation in Cdh23 (Cdh23 p.V2360E). The Cdh23 $3^{\mathrm{V} 2360 \mathrm{E} / \mathrm{V} 2360 \mathrm{E}}$ mice show profound hearing loss at the age of 4 weeks. Many mice (>80\%) had a hearing threshold of $\geq 120 \mathrm{~dB}$ SPL when the ABR was tested at 4 weeks, with the remaining mutants at 110 to $115 \mathrm{~dB}$ SPL.

Heterozygous Cdh23 $3^{\mathrm{V} 2360 \mathrm{E} /+}$ mice had a later onset and milder hearing loss. Therefore, the Cdh23 p.V2360E allele is semidominant because $\mathrm{Cdh} 23^{\mathrm{V} 2360 \mathrm{E} /+}$ heterozygous mice show significantly elevated hearing threshold levels at 24 weeks when compared with wild-type littermates. This finding is in agreement with previous studies $^{36}$ that show mice heterozygous for the Cdh23 ${ }^{v}$ waltzer allele have hearing loss that deteriorates with age and have an increased susceptibility to noise-induced hearing loss. SEM analysis of 13-week-old Cdh23V2360E/+ mice revealed degeneration of hair cells in the basal cochlear region, which is likely to extend throughout the cochlea as the mice age and attribute to the elevated hearing thresholds we observed in these mice at the age of 24 weeks.

Cdh23 forms part of the cochlea hair cell tip link filaments where the protein interacts with PCDH15. ${ }^{18}$ The Cdh23 p.V2360E mutation affects the highly conserved $\mathrm{Ca}^{2+}$-binding VDYE motif located in EC domain 22 (Figure $2 \mathrm{~B}$ ). Amino acid changes in the calcium-binding motifs are likely to cause structural changes and to alter calcium-binding properties. ${ }^{37}$ Our protein modeling supports the hypothesis that the Cdh23 p.V2360E mutation leads to a conformational change that severely interferes with local $\mathrm{Ca}^{2+}$-binding properties, thereby compromising the structural integrity and dimerization capability of the mutant protein.
We detected similar levels of Cdh23 protein localizing to the stereocilia of Cdh23 $3^{\mathrm{V} 2360 \mathrm{E} / \mathrm{V} 2360 \mathrm{E}}$ mutants when compared with wild-type mice at P5 and P14, but Cdh23 was undetectable by P30 in the Cdh23 ${ }^{\mathrm{V} 2360 \mathrm{E} / \mathrm{V} 2360 \mathrm{E}} \mathrm{mu}$ tants. Our SEM analysis of P14 mice (data not shown) revealed no obvious differences between mutant and wild-type mice at this age; stereociliary tenting was observed in IHCs, and hair bundle formation was normal for $\mathrm{IHCs}$ and $\mathrm{OHCs}$. This suggests that, despite being composed of mutant Cdh23 protein, tip links are initially able to form in the Cdh23 ${ }^{\mathrm{V} 2360 \mathrm{E} / \mathrm{V} 2360 \mathrm{E}}$ mice and are intact up until approximately the time of onset of hearing (at P12 to P14). However, we propose that the tip links would be unable to function correctly when hearing would normally be established and would break readily when under tension caused by the deflection of the stereocilia bundle in response to sound. This is supported by reduced tenting of stereocilia tips observed in $\mathrm{HCC}$ at P30 in Cdh23 ${ }^{\mathrm{V} 2360 \mathrm{E} / \mathrm{V} 2360 \mathrm{E}}$ mice, indicating disruption of stereociliary tip links. This also supports the hypothesis that tip links regenerate from the reserve pool of transduction molecules, as suggested by Lelli et al. ${ }^{28}$ However, the rate of regeneration in the Cdh23 $3^{\mathrm{V} 2360 \mathrm{E} / \mathrm{V} 2360 \mathrm{E}}$ mutant would be insufficient to fully reestablish tip links; and the reserve pool would eventually be depleted, rendering the hair cell insensitive to mechanical stimulation. Interestingly, we were still able to detect what appear to be interstereociliary links connecting stereocilia in $\mathrm{OHC}$ hair bundles. Rzadzinska and Steel ${ }^{38}$ reported a similar finding for the $\mathrm{Cdh} 23^{\mathrm{v} 2 \mathrm{~J}}$ waltzer mouse; reduced tenting was observed in the IHCs of the mutant mouse, despite the presence of "tip link-like structures" in hair bundles of both IHCs and OHCs. We hypothesize that the lateral links, which we are able to detect by SEM in P30 mutant mice, may not be under the same degree of tension as the tip links and are, therefore, more likely to remain intact despite incorporating mutant Cdh23 protein. Alternatively, there may be other molecular components that compose the various stereociliary links that might compensate for the presence of mutant Cdh23.

The degeneration of hair cell bundles, most notable in the basal cochlear region, in $C d h 23^{\mathrm{V} 2360 \mathrm{E} / \mathrm{V} 2360 \mathrm{E}}$ mice at $\mathrm{P} 30$ (and also in the Cdh23 $3^{\mathrm{V} 2360 \mathrm{E} /+}$ mice at 13 weeks) is likely to be a secondary consequence of the hair cells being nonfunctional.

In humans, mutations in $\mathrm{CDH} 23$ can cause deafnessblindness (USH1D) or nonsyndromic deafness (DFNB12). CDH23-null mutations appear to cause USH1D, whereas missense mutations cause nonsyndromic deafness. ${ }^{2}$ Most mice with Cdh23 mutations present with the waltzer phenotype: hearing loss and vestibular dysfunction. ${ }^{9-13}$ However, in mice, mutations in Cdh23 have not been associated with retinal degeneration. Gene expression studies $^{29}$ have shown that the longest Cdh23 isoform (CDH23_V1) is expressed in the primate retina but not in the murine retina. This Cdh23 isoform was the only isoform affected by the Cdh23 ${ }^{\mathrm{V} 6 \mathrm{~J}}$ nonsense mutation located in EC domain 3. Tissue-specific differences in the expression of the long isoform of $\mathrm{Cdh} 23$ in human and mouse eyes could explain why no retinal degeneration is seen in waltzer mice. ${ }^{29}$ Waltzer mutations are predomi- 

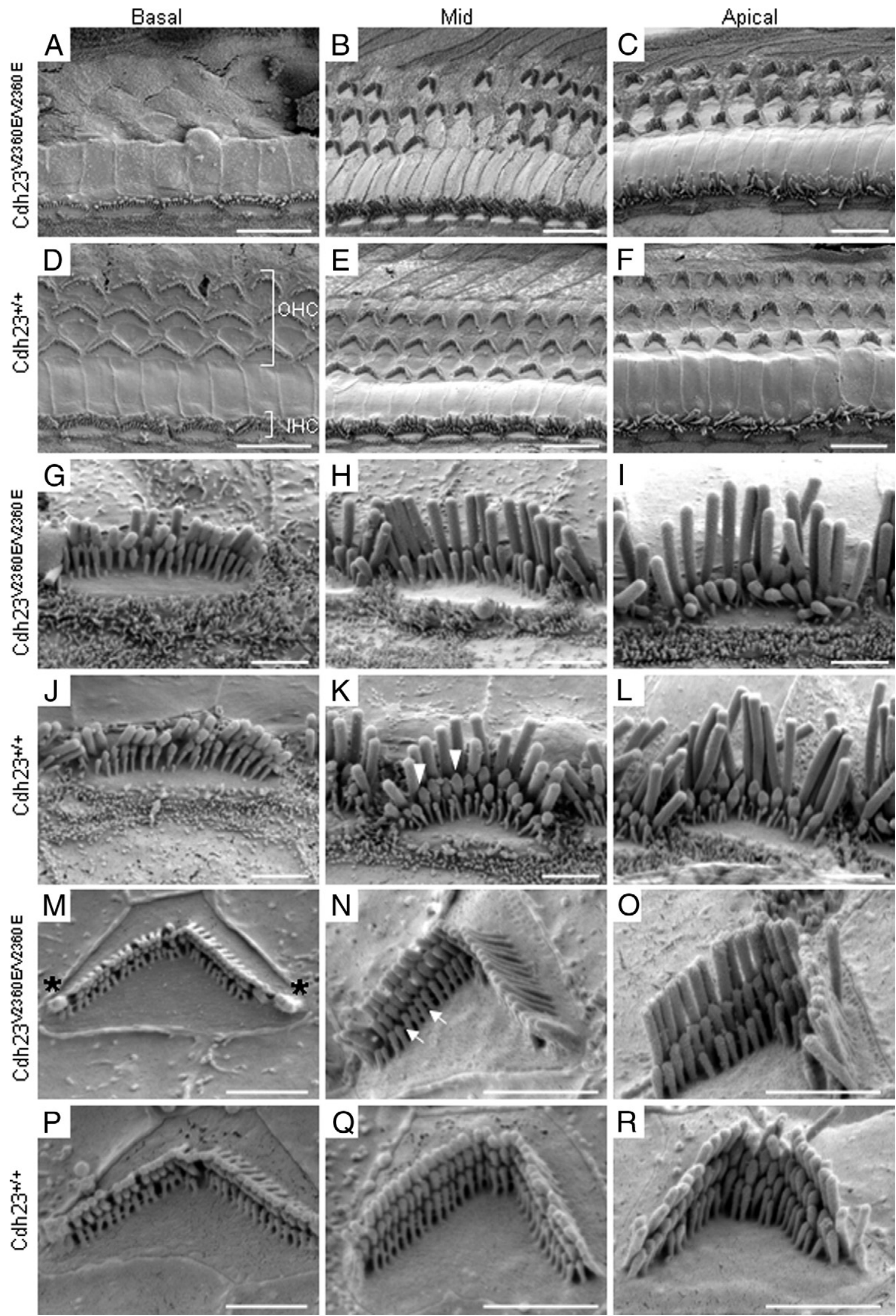

Figure 9. Disruption of tip links and hair cell degeneration in P30 Cdh23 $3^{\mathrm{V} 2360 \mathrm{E} / \mathrm{V} 2360 \mathrm{E}}$ mice. A through F: SEM images of the cochlear SE reveal loss of OHCs in the basal through the midcochlear region in $C d h 23^{\mathrm{V} 2360 \mathrm{E} / \mathrm{V} 2360 \mathrm{E}}$ mice. $\mathbf{G}$ through $\mathbf{L}$ : An examination of IHCs indicates a defect in stereociliary tip tenting (shown by peaked stereocilia tips: arrowheads in $\mathbf{K}$ ) in $C d h 23^{\mathrm{V} 2360 \mathrm{E} / \mathrm{V} 2360 \mathrm{E}}$ mice, most obvious in the mid and apical regions. M through R: OHCs appeared normal in the mid to apical region of $C d h 23^{\mathrm{V} 2360 \mathrm{E} / \mathrm{V} 2360 \mathrm{E}}$ mice. Lateral links could be observed between stereocilia (arrows in N). Basal OHCs (M), when still present, showed signs of degeneration, such as fused stereocilia (asterisk). Scale bars: $10 \mu \mathrm{m}(\mathbf{A}-\mathbf{F}) ; 2 \mu \mathrm{m}(\mathbf{G}-\mathbf{R})$ 

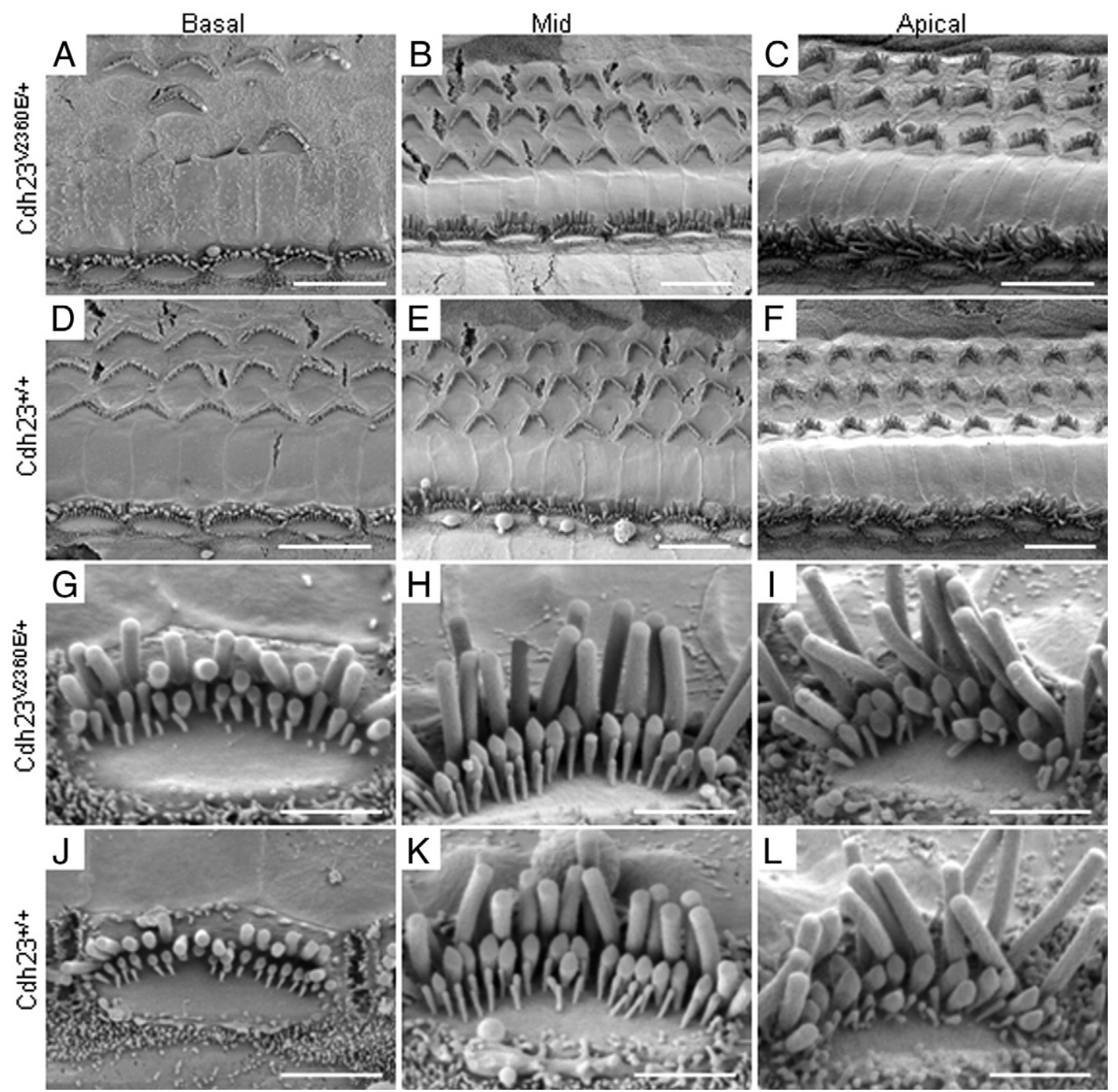

Figure 10. A through F: Cdh $23^{\mathrm{V} 2360 \mathrm{E} /+}$ mice show degeneration of basal hair cells. SEM analysis of cochlear SE revealed substantial OHC loss in the basal turn of $C d h 23^{\mathrm{V} 2360 \mathrm{E} /+}$ mice compared with $C d h 23^{+/+}$mice. G through L: The results of an examination of IHC stereocilia indicated normal tip tenting in Cdh $23^{\mathrm{V} 2360 \mathrm{E} /+}$ mice. Scale bars: $10 \mu \mathrm{m}(\mathbf{A}-\mathbf{F}) ; 2 \mu \mathrm{m}(\mathbf{G}-\mathbf{L})$.

nantly located in EC domains and appear to be functional null alleles. ${ }^{9-11}$ The null mutations in waltzer mice result in lack of organization of cochlear hair cell stereocilia and misplaced kinocilia. ${ }^{39,40}$ Recently, two ENU-generated Cdh23 mouse mutants, salsa and erlong, were reported; recessively inherited progressive hearing loss commenced at 3 to 4 weeks without any vestibular dysfunction, unlike the waltzer mutants. ${ }^{14,15}$ The salsa mutant harbors a point mutation, Cdh23 p.E737V, that is located in the more distal EC7 $\mathrm{Ca}^{2+}$-binding domain and leads to loss of tip links and tenting of stereociliary tips because of its effect on interaction/binding with Pcdh $15 .{ }^{14}$ The erlong missense mutation Cdh23 p.S70P resides in the EC1 domain but not within a $\mathrm{Ca}^{2+}$-binding motif and has a less severe hearing loss phenotype than salsa. ${ }^{15}$ Similar to salsa, the jera Cdh23 p.V2360E missense mutation is located within a $\mathrm{Ca}^{2+}$-binding domain in EC22. A similar process of tip link loss occurs in the jera mutant, as reported in salsa. Our results also support the hypothesis that missense mutations in a $\mathrm{Ca}^{2+}$-binding domain affect mechanotransduction, but not hair bundle development, because hair bundles appear normal at P14. The deafness observed in these mutants suggests a genotypephenotype correlation in which missense mutations residing in $\mathrm{Ca}^{2+}$-binding domains lead to severe hearing loss and increased severity influenced by the location of the mutation. Because the mutant protein is present in the stereocilia links of affected mice, hair bundle development could be regulated by another Cdh23 domain and perhaps its interaction with other proteins. The data we present herein provide supportive evidence that the Cdh23 protein is directly involved in establishing a stereociliary tip link and tenting, which are crucial for the mechanotransduction process.

Furthermore, polymorphisms in $\mathrm{CDH} 23$ have been associated with noise-induced hearing loss in humans. 
Mice carriers for the Cdh23 waltzer-null allele show increased susceptibility to noise trauma. The compilation of well-characterized allelic variants in the Cdh23 gene (or any other deafness gene) provides a great opportunity to generate a "carrier susceptibility matrix" to environmental insults, including predisposition to noise trauma or ototoxic drugs. This information would be extremely useful in the detection, counseling, and management of patients and their families (who are carriers) with DFNB12 hearing loss.

In conclusion, jera is a novel mouse model for deciphering the molecular pathways that lead to the different forms of DFNB12 hearing loss that will enable more detailed studies on the role of Cdh23 in the development and function of cochlear hair cells, its role in stereocilia tip link mechanotransduction, and its role for screening otoprotective drugs under the various DFNB12 conditions.

\section{Acknowledgments}

We thank the Australian Phenomics Facility for its contribution, Jessica Cardwell and Melissa Arnold for their technical help, and Prof. Thomas Friedman and Dr. Ayala Lagziel (National Institute on Deafness and Other Communication Disorders) for providing the TF8Cdh23 antibody.

\section{References}

1. Petit C: Genes responsible for human hereditary deafness: symphony of a thousand. Nat Genet 1996, 14:385-391

2. Bork JM, Peters LM, Riazuddin S, Bernstein SL, Ahmed ZM, Ness SL, Polomeno R, Ramesh A, Schloss M, Srisailpathy CR, Wayne S, Bellman S, Desmukh D, Ahmed Z, Khan SN, Kaloustian VM, Li XC, Lalwani A, Riazuddin S, Bitner-Glindzicz M, Nance WE, Liu XZ, Wistow G, Smith RJ, Griffith AJ, Wilcox ER, Friedman TB, Morell RJ: Usher syndrome 1D and nonsyndromic autosomal recessive deafness DFNB12 are caused by allelic mutations of the novel cadherin-like gene CDH23. Am J Hum Genet 2001, 68:26-37

3. Bolz H, von Brederlow B, Ramírez A, Bryda EC, Kutsche K, Nothwang HG, Seeliger M, del C-Salcedó Cabrera M, Vila MC, Molina OP, Gal A Kubisch C: Mutation of $\mathrm{CDH} 23$, encoding a new member of the cadherin gene family, causes Usher syndrome type 1D. Nat Genet 2001, 27:108-112

4. Friedman TB, Griffith AJ: Human nonsyndromic sensorineural deafness. Annu Rev Genomics Hum Genet 2003, 4:341-402

5. Astuto LM, Bork JM, Weston MD, Askew JW, Fields RR, Orten DJ, Ohliger SJ, Riazuddin S, Morell RJ, Khan S, Riazuddin S, Kremer H, van Hauwe P, Moller CG, Cremers CW, Ayuso C, Heckenlively JR, Rohrschneider K, Spandau U, Greenberg J, Ramesar R, Reardon W, Bitoun P, Millan J, Legge R, Friedman TB, Kimberling WJ: CDH23 mutation and phenotype heterogeneity: a profile of 107 diverse families with Usher syndrome and nonsyndromic deafness. Am J Hum Genet 2002, 71:262-275

6. Oshima A, Jaijo T, Aller E, Millan JM, Carney C, Usami S, Moller C, Kimberling WJ: Mutation profile of the $\mathrm{CDH} 23$ gene in 56 probands with Usher syndrome type I. Hum Mutat 2008, 29:E37-E46

7. Becirovic E, Ebermann I, Nagy D, Zrenner E, Seeliger MW, Bolz HJ: Usher syndrome type 1 due to missense mutations on both $\mathrm{CDH} 23$ alleles: investigation of mRNA splicing. Hum Mutat 2008, 29:452

8. Noben-Trauth K, Zheng QY, Johnson KR: Association of cadherin 23 with polygenic inheritance and genetic modification of sensorineural hearing loss. Nat Genet 2003, 35:21-23

9. Di Palma F, Holme RH, Bryda EC, Belyantseva IA, Pellegrino R, Kachar B, Steel KP, Noben-Trauth K: Mutations in Cdh23, encoding a new type of cadherin, cause stereocilia disorganization in waltzer, the mouse model for Usher syndrome type 1D. Nat Genet 2001, 27:103-107

10. Di Palma F, Pellegrino R, Noben-Trauth K: Genomic structure, alternative splice forms and normal and mutant alleles of cadherin 23 (Cdh23). Gene 2001, 281:31-41

11. Yonezawa S, Yoshizaki N, Kageyama T, Takahashi T, Sano M, Tokita Y, Masaki S, Inaguma Y, Hanai A, Sakurai N, Yoshiki A, Kusakabe M, Moriyama A, Nakayama A: Fates of $\mathrm{Cdh} 23 / \mathrm{CDH} 23$ with mutations affecting the cytoplasmic region. Hum Mutat 2006, 27:88-97

12. Wada T, Wakabayashi $Y$, Takahashi S, Ushiki T, Kikkawa $Y$, Yonekawa $\mathrm{H}$, Kominami $\mathrm{R}$ : A point mutation in a cadherin gene, Cdh23, causes deafness in a novel mutant, Waltzer mouse niigata. Biochem Biophys Res Commun 2001, 283:113-117

13. Wilson SM, Householder DB, Coppola V, Tessarollo L, Fritzsch B, Lee EC, Goss D, Carlson GA, Copeland NG, Jenkins NA: Mutations in Cdh23 cause nonsyndromic hearing loss in waltzer mice. Genomics 2001, 74:228-233

14. Schwander M, Xiong W, Tokita J, Lelli A, Elledge HM, Kazmierczak P, Sczaniecka A, Kolatkar A, Wiltshire T, Kuhn P, Holt JR, Kachar B, Tarantino L, Muller U: A mouse model for nonsyndromic deafness (DFNB12) links hearing loss to defects in tip links of mechanosensory hair cells. Proc Natl Acad Sci U S A 2009, 106:5252-5257

15. Han F, Yu H, Tian C, Chen HE, Benedict-Alderfer C, Zheng Y, Wang Q, Han X, Zheng QY: A new mouse mutant of the Cdh23 gene with early-onset hearing loss facilitates evaluation of otoprotection drugs. Pharmacogenomics J 2010, [Epub ahead of press] doi:10.1038/ tpj.2010.60

16. Siemens J, Lillo C, Dumont RA, Reynolds A, Williams DS, Gillespie $P G$, Muller $U$ : Cadherin 23 is a component of the tip link in hair-cell stereocilia. Nature 2004, 428:950-955

17. Sollner C, Rauch GJ, Siemens J, Geisler R, Schuster SC, Muller U, Nicolson T: Mutations in cadherin 23 affect tip links in zebrafish sensory hair cells. Nature 2004, 428:955-959

18. Kazmierczak $P$, Sakaguchi H, Tokita J, Wilson-Kubalek EM, Milligan RA, Muller U, Kachar B: Cadherin 23 and protocadherin 15 interact to form tip-link filaments in sensory hair cells. Nature 2007, 449:87-91

19. Beurg M, Fettiplace R, Nam JH, Ricci AJ: Localization of inner hair cel mechanotransducer channels using high-speed calcium imaging. Nat Neurosci 2009, 12:553-558

20. Sotomayor M, Weihofen WA, Gaudet R, Corey DP: Structural determinants of cadherin-23 function in hearing and deafness. Neuron 2010, 66:85-100

21. Alagramam KN, Murcia CL, Kwon HY, Pawlowski KS, Wright CG, Woychik RP: The mouse Ames waltzer hearing-loss mutant is caused by mutation of Pcdh15, a novel protocadherin gene. Nat Genet 2001 27:99-102

22. Gibson F, Walsh J, Mburu P, Varela A, Brown KA, Antonio M, Beisel KW, Steel KP, Brown SD: A type VII myosin encoded by the mouse deafness gene shaker-1. Nature 1995, 374:62-64

23. Johnson KR, Gagnon LH, Webb LS, Peters LL, Hawes NL, Chang B, Zheng QY: Mouse models of USH1C and DFNB18: phenotypic and molecular analyses of two new spontaneous mutations of the Ush1c gene. Hum Mol Genet 2003, 12:3075-3086

24. Kikkawa Y, Shitara H, Wakana S, Kohara Y, Takada T, Okamoto M, Taya C, Kamiya K, Yoshikawa Y, Tokano H, Kitamura K, Shimizu K, Wakabayashi Y, Shiroishi T, Kominami R, Yonekawa H: Mutations in a new scaffold protein Sans cause deafness in Jackson shaker mice. Hum Mol Genet 2003, 12:453-461

25. Lefevre G, Michel V, Weil D, Lepelletier L, Bizard E, Wolfrum U, Hardelin JP, Petit C: A core cochlear phenotype in USH1 mouse mutants implicates fibrous links of the hair bundle in its cohesion, orientation and differential growth. Development 2008, 135:14271437

26. Pawlowski KS, Kikkawa YS, Wright CG, Alagramam KN: Progression of inner ear pathology in Ames waltzer mice and the role of protocadherin 15 in hair cell development. J Assoc Res Otolaryngol 2006, 7:83-94

27. Senften M, Schwander M, Kazmierczak P, Lillo C, Shin JB, Hasson T, Geleoc GS, Gillespie PG, Williams D, Holt JR, Muller U: Physical and functional interaction between protocadherin 15 and myosin VIla in mechanosensory hair cells. J Neurosci 2006, 26:2060-2071

28. Lelli A, Kazmierczak P, Kawashima Y, Muller U, Holt JR: Development and regeneration of sensory transduction in auditory hair 
cells requires functional interaction between cadherin-23 and protocadherin-15. J Neurosci 2010, 30:11259-11269

29. Lagziel A, Overlack N, Bernstein SL, Morell RJ, Wolfrum U, Friedman TB: Expression of cadherin 23 isoforms is not conserved: implications for a mouse model of Usher syndrome type 1D. Mol Vis 2009, 15: 1843-1857

30. Whitlon DS, Szakaly R, Greiner MA: Cryoembedding and sectioning of cochleas for immunocytochemistry and in situ hybridization. Brain Res Brain Res Protoc 2001, 6:159-166

31. Nagar B, Overduin M, Ikura M, Rini JM: Structural basis of calciuminduced E-cadherin rigidification and dimerization. Nature 1996, 380: 360-364

32. Phillips JC, Braun R, Wang W, Gumbart J, Tajkhorshid E, Villa E, Chipot C, Skeel RD, Kale L, Schulten K: Scalable molecular dynamics with NAMD. J Comput Chem 2005, 26:1781-1802

33. Humphrey W, Dalke A, Schulten K: VMD: visual molecular dynamics. J Mol Graph 1996, 14:33-38, 27-28

34. Roux AF, Faugere V, Le Guedard S, Pallares-Ruiz N, Vielle A, Chambert S, Marlin S, Hamel C, Gilbert B, Malcolm S, Claustres M: Survey of the frequency of USH1 gene mutations in a cohort of Usher patients shows the importance of cadherin 23 and protocadherin 15 genes and establishes a detection rate of above 90\%. J Med Genet 2006, 43:763-768
35. Sotomayor M, Corey DP, Schulten K: In search of the hair-cell gating spring elastic properties of ankyrin and cadherin repeats. Structure 2005, 13:669-682

36. Holme RH, Steel KP: Progressive hearing loss and increased susceptibility to noise-induced hearing loss in mice carrying a Cdh23 but not a Myo7a mutation. J Assoc Res Otolaryngol 2004, 5:66-79

37. de Brouwer AP, Pennings RJ, Roeters M, Van Hauwe P, Astuto LM, Hoefsloot LH, Huygen PL, van den Helm B, Deutman AF, Bork JM, Kimberling WJ, Cremers FP, Cremers CW, Kremer H: Mutations in the calcium-binding motifs of $\mathrm{CDH} 23$ and the $35 \mathrm{delG}$ mutation in GJB2 cause hearing loss in one family. Hum Genet 2003, 112:156163

38. Rzadzinska AK, Steel KP: Presence of interstereocilial links in waltzer mutants suggests Cdh23 is not essential for tip link formation. Neuroscience 2009, 158:365-368

39. Holme RH, Steel KP: Stereocilia defects in waltzer (Cdh23), shaker1 (Myo7a) and double waltzer/shaker1 mutant mice. Hear Res 2002 169:13-23

40. Lagziel A, Ahmed ZM, Schultz JM, Morell RJ, Belyantseva IA, Friedman TB: Spatiotemporal pattern and isoforms of cadherin 23 in wild type and waltzer mice during inner ear hair cell development. Dev Biol 2005, 280:295-306 